\title{
İnsansız Sualtı Araçlarında (İSA) Hidrodinamik Sürüklenme ve Kaldırma Kuvvetlerinin Derinlik ve Hıza Bağlı Değişiminin HAD İle Analizi
}

\section{Analysis of Depth and Speed-Dependent Variation of Hydrodynamic Drift and Lift Forces in Unmanned Underwater Vehicles (UUV) with CFD}

\author{
Gülten Yılmaz", iD, Serhat Yılmaz ${ }^{2}$ iD \\ ${ }^{1}$ Kocaeli Üniversitesi Hereke Asım Kocabılk MYO. Elektronik Otomasyon Bölümü, 41800-Kocaeli,TÜRKIYE \\ ${ }^{2}$ Kocaeli Üniversitesi Mühendislik Fakültesi Elektronik Haberleşme Mühendisliği Bölümü, 41300 Kocaeli, TÜRKIYYE
}

Başvuru/Received: 07/06/2021

Kabul / Accepted: 03/10/2021

Çevrimiçi Basım / Published Online: 31/01/2022

Son Versiyon/Final Version: 31/01/2022

\begin{abstract}
$\ddot{O} \mathbf{z}$
Günümüzde İnsansız Sualtı Araçları (İSA), okyanus ve denizaltı keşifleri için sıklıkla kullanılmaktadır. Su yüzeyine yakın hareket eden İSA'ların hidrodinamiği, daha derinde hareket eden İSA'lara göre önemli farklılıklar gösterir. Bu makalede bir İSA'nın, yatay ve dikey doğrultularda, farklı derinliklerde $(0.5 \mathrm{~m}, 1 \mathrm{~m}, 1.5 \mathrm{~m}, 2 \mathrm{~m}$ ve $2.5 \mathrm{~m})$ ve hızlarda $(0.1 \mathrm{~m} / \mathrm{s}, 0.5 \mathrm{~m} / \mathrm{s} \mathrm{ve} 1 \mathrm{~m} / \mathrm{s})$ yapmış olduğu hareketler sırasında, gövdesi üzerine etki eden hidrodinamik sürüklenme kuvvetleri, kaldırma kuvvetleri ve bunlara bağlı olarak sürüklenme ve kaldırma katsayıları belirlenmeye çalışılmışıı. Çalışmanın amacı, Hesaplamalı Akışkanlar Dinamiği (HAD) analiz yöntemlerini kullanarak derinlik ve akış hızının hidrodinamik parametreler üzerindeki etkisini gözlemektir. Sayısal analizlerden elde edilen değerlerin doğruluğunu desteklemek için deneysel çalışmalar yapılarak sonuçlar karşılaştırılmıștır. Analiz amaçlı simulasyonlarda, 2018-108 nolu Kocaeli Üniversitesi Bilimsel Araştırma Projeleri (KOU-BAP) biriminden altyapı desteği alınarak geliştirilen, dört serbestlik dereceli İSA'nın SolidWorks yardımı ile bire bir ölçülerde tasarlanan 3 boyutlu CAD modeli kullanılmıştır. Flow Simulation ticari yazılımı, SolidWorks programıyla birlikte çalışabilen bir HAD yazılımıdır ve laminar ve türbülanslı akış analizleri için Navier Stokes denklemlerinin çözümünden yararlanır. Bu çalışmada, laminar akıştan türbülanslı akışa geçiş durumu için Flow Simulation k-e türbülans modeli kullanılmıştır.
\end{abstract}

\section{Anahtar Kelimeler}

“CAD Model, Sürüklenme Kuvveti, Kaldırma Kuvveti, Sürüklenme Katsayısı, Kaldırma Katsayısı”

\begin{abstract}
Unmanned Underwater Vehicles (UUV) are frequently used today for ocean and submarine exploration. The hydrodynamic properties of UUV's moving close to the water surface are quite different from those moving at deeper depths. In this article, an UUV's has done at different depths $(0.5 \mathrm{~m}, 1 \mathrm{~m}, 1.5 \mathrm{~m}, 2 \mathrm{~m}$ and $2.5 \mathrm{~m})$ and velocities $(0.1 \mathrm{~m} / \mathrm{s}, 0.5 \mathrm{~m} / \mathrm{s}$ and $1 \mathrm{~m} / \mathrm{s})$ in horizontal and vertical directions, during the movements, the hydrodynamic drag forces, the lift forces acting on the hull and the drag and lift coefficients depending on these were tried to be determined. The aim of the study is to observe the effects of depth and flow velocity on hydrodynamic parameters by using Computational Fluid Dynamics (CFD) analysis methods. The accuracy of the values obtained from numerical analyzes was tried to be proven by conducting experimental studies. In the simulations for analysis, a threedimensional CAD model of the four-degrees-of-freedom UUV, which was developed with the infrastructure support of the Kocaeli University Scientific Research Projects (KOU-SRP) unit, numbered 2018-108, was used. Flow Simulation commercial software is a CFD software interoperable with SolidWorks and utilizes the solution of Navier Stokes equations for laminar and turbulent flow analysis. In this study, the Flow Simulation k- $\varepsilon$ turbulence model was used for the transition from laminar flow to turbulent flow.
\end{abstract}

Key Words

"CAD Model, Drag Force, Lift Force, Drag Coefficient, Lifting Coefficient" 


\section{Giriş}

Derin denizleri keşfetmek için yapılan çalışmalarda, denizaltında insan varlığına duyulan ihtiyacı ortadan kaldıracak uygun alet ve ekipmanların tasarlanması, bu çalışmaların hızlı ve güvenli yapılabilmesi için oldukça önemlidir. Bu amaçla, çeşitli insansız denizaltılar geliştirilmiştir. İnsansız Sualtı Araçları (İSA'lar) veya uzaktan kontrol edilebilen sualtı araçları (ROV'lar), ölçüm ve deniz dibi araştırmaları, mayın taramaları, doğalgaz ve petrol araştırmaları, gemi altı hasarlarının tespiti ve bakımı gibi birçok uygulamada kullanılmaktadır (Yakut vd., 2015). Araçların gövde şekilleri, kullanım amaçlarına uygun olacak şekilde tasarlanır. Literatürde en çok rastlananlar, sürüklenme kuvvetlerinin düşük olması nedeniyle enerji tüketimleri daha az olan, akım çizgili tasarıma sahip, silindirik veya torpido şeklindeki İSA'lardır. Diğer bir tür ise, daha kısa süreli görevler için veya buzdağları, barajlar gibi sualtı nesnelerini araştıran İSA'lar, bu hidrodinamik yapıdan farklı olabilmektedir. İSA'ların hidrodinamik parametrelerinin, analitik yöntemlerle belirlendiği eşitlikler ise sadece silindirk veya torpido şekilli araçlar için geçerlidir. Bu durum, karmaşık geometriye sahip İSA' veya ROV'ların hidrodinamik parametrelerinin belirlenmesi işlemini güçleştirmektedir. Bu tür araçların, hidrodinamik parametreleri yalnızca ve en doğru olarak havuz deneyleri ve HAD analizleri ile bulunabilir.

İSA'ların denizdeki çalışma koşulları üç kategoriye ayrılabilir; deniz yüzeyi civarında, orta derinliklerde ve deniz tabanı yakınında. Su altı araçlarının tasarımındaki ana zorluk, manevra kabiliyetini korurken yeteneklerini farklı çalışma koşullarıyla eşleştirmektir. İSA'ların deniz yüzeyine yakın yatay hareketleri sırasında dalga oluşturma eğilimleri, eksenel simetriye sahip araçlar için bile sıfır olmayan kaldırma kuvvetleri ve eğim (pitch) momentleri oluşturur. Bu etkiler nedeniyle, deniz yüzeyine yakın hareket eden İSA'lar için dinamik stabilite sağlamak büyük önem ve karmaşıklığa sahiptir. Çalışmaları sırasında, bir İSA özellikle GPS (Global Positioning System) navigasyonundan veri alırken sık sık deniz yüzeyine yaklaşır. Bu nedenle, deniz yüzeyine yakın ve farklı hızlarda hareket eden deniz altı araçlarına etki eden hidrodinamik kuvvet ve momentlerin değerlendirilmesi önemlidir. Tamamen suya daldırılmış hareketli İSA'ların hidrodinamik performansını değerlendirmek için, sıvı akışını tanımlayan denklemlerin doğru bir şekilde çözülmesi gerekir. Pratik olarak, bu denklemlerdeki kuvvetler ve momentler hidrodinamik katsayılar cinsinden ifade edildiğinden, bu katsayılar bir prototip oluşturmadan önce elde edilmelidir. Özellikle deniz yüzeyinden derinde hareket eden, eksenel simetriye sahip araçlar için hidrodinamik katsayıların hesaplamasında kullanılabilecek yöntemler deneysel, yarı deneysel ve sayısal yöntemler olarak sinıflanabilir. Bununla birlikte suya daldırılmış, hareketli bir araç deniz yüzeyi yakınına ulaştı̆ı̆ında, yüksek veya orta derinlikler için hesaplanan katsayılar artık geçerli değildir ve bu koşullarda manevra kabiliyeti ve stabiliteyi değerlendirmek için kullanılamaz. Bu durumda, araç gövdesinin hareket dinamikleri, serbest yüzey dalgalarından etkilenir. Dalma derinliğinin fonksiyonu olarak, bir İSA'nın hidrodinamik katsayılarının tahmini, farklı çalışma koşullarına ait doğru dinamik modellerin elde edilmesi için son derece önemlidir.

Deniz yüzeyine yakın hareket eden İSA'ların genel direnci, iki bileşenden oluşur: sürtünme ve basıncın neden olduğu viskoz direnç ve dalgalanmaların oluşturduğu direnç (Varus ve Paulling, 2010). Hidrodinamik katsayıları hesaplamak için kullanılan sayısal tekniklerdeki son gelişmeler ile ilgili uygun çözümler sunmuşlardır. Hesaplamalı Akışkanlar Dinamiğine (HAD) dayalı sonlu hacim yöntemleri, su yüzeyinin, su altı araçları üzerindeki etkisini simüle etmek için oldukça başarılıdır. Sualtı araçlarının hidrodinamik özelliklerinin, yüzeye yakın ve daha derinlerde tespit edilmesi alanında, araştırmacılar tarafından havuz testleri ve HAD akış analizleri şeklinde birçok çalışma yapılmıştır. Örneğin, (Zhao vd., 2009) ve (Shao vd., 2013), dikey ve eğik silindirler etrafındaki sabit akış1 sayısal olarak çözmüşlerdir. (Malavasi ve Guadagnini, 2007), bir sualtı aracına etki eden hidrodinamik kuvvetleri ve bu kuvvetlere bağlı katsayıları, bir kanal tabanından çeşitli yükseklikler için incelemişlerdir. (Novais vd., 2012), bir insanın 3B CAD modeli ile gerçekleştirdikleri akış analizlerinden, farklı derinliklerde yüzerken insan gövdesine etki eden hidrodinamik kuvveti tahmin etmişlerdir. Enerji verimliliği açısından en uygun derinliği belirlemeye çalışmışlardır. (Salari ve Rava, 2017), bir otonom sualtı aracının bulunduğu derinlik mesafesini, aracın çap uzunluğuna bölerek boyutsuz hale getirilen derinliklerde, $(0.75 \mathrm{D}, 1 \mathrm{D}, 1.5 \mathrm{D}, 2 \mathrm{D}$ ve $4 \mathrm{D}$, D: Aracın çapı) çeşitli hidrodinamik parametreleri, elde etmişlerdir. (Javanmard ve Mansoorzadeh, 2019), torpido şeklindeki bir İSA'nın sürüklenme ve kaldırma katsayılarını, farklı çalışma derinlikleri için ANSYS Fluent programı kullanarak analiz etmişlerdir. (Yang vd., 2015), karmaşık geometrik yapıya sahip bir ROV'un hidrodinamik parametrelerinin akış hızlarına bağlı analizini ANSYS Fluent ticari programı yardımıyla yapmışlardır. (Du vd., 2014), deniz dibine yakın hareket eden bir İSA'nın hidrodinamik parametrelerinin, atak açısına bağlı değişimlerini ANSYS ICEM ticari programı yardımı ile incelemişlerdir.

ISA' lara, hareketleri sırasında etki eden kuvvet ve momentlerin, doğrusal ve açısal hızlanmalara bağlı değişimlerini ifade eden fonksiyonların katsayıları, hidrodinamik türevler olarak nitelendirilir. Hidrodinamik trevleri tahmin etmek için de önemli çalışmalar yapılmıştır. Örneğin; (Zhang vd., 2010), Sualtı araçlarının hidrodinamik türevlerinin (ek kütle ve sönümleme) deneysel yöntemler ile tahmininde sıklıkla kullanılan Düzlemsel Hareket Mekanizması (DHM)'nı Fluent yazılımını kullanarak modellemişler ve hidrodinamik türevleri bu şekilde tahmine çalışmışlardır. (Mitra vd., 2021), ISSA gövdesine yönelik hidrodinamik özellikleri araştırmak için eğimli kanal yatakları üzerinde, farklı Reynolds sayılarındaki akış amalizleri ile deneysel çalışmaları birlikte yürüterek sonuçları karşılaştırmışlardır. (Karasu, 2019), Reynolds sayısının 5000'den küçük olduğu durumlar için, silindir etrafındaki kararsız akışı farklı türbülans modelleri ile sayısal olarak incelemiş ve bu modellerin performanslarını karşılaştırmıştır. Çalışmada, aynı şartlarda aynı ağ yapısında türbülans modelleri olarak LES, k- $\omega$ tabanlı DES, k- $\varepsilon$ Realizable ve k-kL- $\omega$ transition modelleri kullanılmıştır. Mansoorzadeh ve (Javanmard, 2014), Serbest yüzey akışlarının, sualtı aracının sürüklenme ve kaldırma katsayıları üzerindeki etkisini araştırmak için HAD programı yardımı ile iki fazlı akış için Reynolds Ortalamalı Navier-Stokes (RANS) denklemlerinin çözümünü gerçekleştirmişlerdir. Elde edilen sayısal sonuçları, İsfahan Teknoloji Üniversitesi Denizaltı Ar-Ge Merkezi'nin çekme tankında yapılan deneylerden elde edilen sonuçlar ile karşılaştırmışlar ve birbirine yakın değerler olduklarını göstermiş̧lerdir. 
Tamamen suya batmış olan bir sualtı aracının sabit hızda veya ivmeli hareketi için iticilerin, araç ataletini ve akışkandan kaynaklı hidrodinamik kuvvetleri yenecek miktarda güç üretmesi gerekir. Özellikle otonom araçların uzun süre su altında görev yapabilmeleri açısından enerji verimliliği önemli bir konudur. Bu kapsamda farklı hız, derinlik ve atak açıları ile hareketleri sırasında sualtı araçlarına etki eden hidrodinamik kuvvet ve momentlerin belirlenmesi önemlidir. Literatürde yer alan araştırmalar incelendiğinde, büyük çoğunluğu akım çizgili tasarıma sahip sualtı araçları olduğu ve genellikle atak açısına bağlı olarak sürüklenme ve kaldırma katsayılarının değişiminin araştırıldığı çalışmalar olduğu görülmüştür. Bu çalışma, karmaşık geometrik yapılı bir aracın sürüklenme ve kaldırma katsayılarının derinlik ve akış hızına bağlı değişimini, karşılaştırmalı olarak araştırdığı için farklıdır. Böylelikle, aracın enerji tüketimi açısından hangi derinlikte ve hızda çalıştırılmasının daha uygun olacağına karar verilebilecektir. Ayrıca, tasarım aşamasında derinliğe bağlı basınç ölçümleri ile araç gövdesinde kullanılabilecek doğru malzemenin seçilmesine de katkı sağlayacaktır. Bütün bunlar, çalışmanın önemini artırmaktadır.

\section{Dış Akış Analizi}

Akışkanın, durağan bir katı cisim üzerinden hareket etmesi veya durağan bir akışkan içerisinde katı bir cismin hareket etmesi sırasında oluşacak hidrodinamik kuvvet ve momentlerin hesaplandığı problemler, dış akış problemleri olarak tanımlanır (Öztop, 2014). Bir İSA'nın 6 serbestlik dereceli genel hareketi; 3 doğrusal kuvvet ve 3 açısal momentum denklemi ile tanımlanır. Bazı durumlarda, akış alanları ve araç geometrisi, dış akış problemlerinin analitik yollarla çözülemeyeceği kadar karmaşık olabilir. Bu durmlarda, sualtı araçlarının dinamik sistem modellerinin belirlenmesi için gerekli olan hidrodinamik parametrelerin (ek kütle, sönümleme ve coriolis etkisi), hesaplanması sırasında, dış akış problemlerinin sayısal çözümünden yararlanılır.

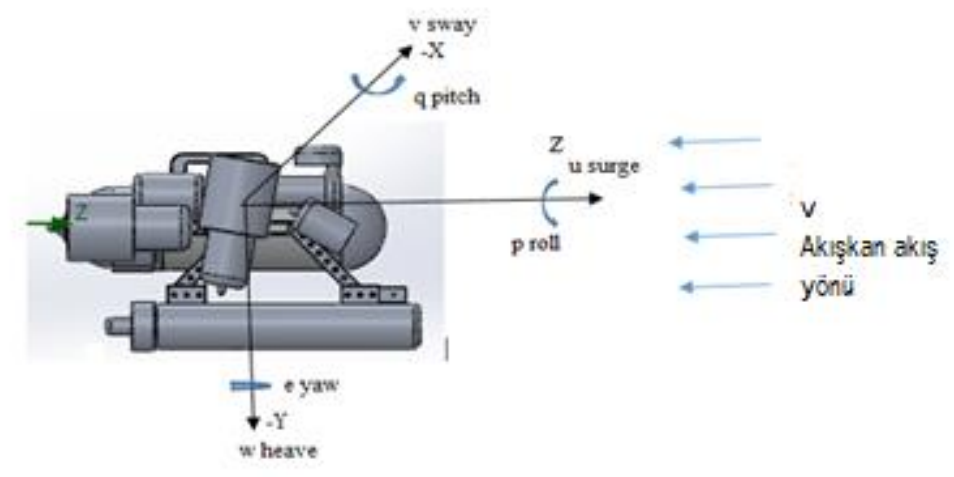

Şekil 1. Akışa bağlı kuvvet ve momentler (FlowSimulation koordinat sisyemi için tanımlı)

Kaldırma ve sürüklenme kuvvetleri, araç yüzeyi boyunca basınç ve çeper-kayma gerilmesinin integrali ile bulunur (Öztop, 2014).

$F_{D}=\int_{A} d F_{D}=\int\left(-P \cdot \operatorname{Cos} \theta+\tau_{\omega \cdot} \operatorname{Sin} \theta\right) d A$

$F_{L}=\int_{A} d F_{L}=-\int\left(P \cdot \operatorname{Sin} \theta+\tau_{\omega \cdot} \operatorname{Cos} \theta\right) d A$

Kaldırma kuvveti $F_{L}$ ve sürüklenme kuvveti $F_{D}$, araç geometrisine, akışkanın yoğunluğuna $(\rho)$ ve hızına (v) bağlıdır. Kaldırma ve sürüklenme kuvvet katsayıları boyutsal analiz ile eşitlik (3) ve (4)’teki gibi ifade edilr.

$C_{D}=\frac{F_{D}}{\frac{1}{2} \cdot \rho \cdot V^{2} A}$

$C_{L}=\frac{F_{L}}{\frac{1}{2} \cdot \rho \cdot V^{2} A}$

Burada A, hidrodinamik uygulamalar için ıslak yüzey alanıdır. Dış akışa bağlı kuvvetler, akışkanın yüzey üzerinde oluşturduğu basınç ve sürtünmelerden kaynaklanır.

$\mathrm{F}_{\mathrm{D}}=\mathrm{F}_{\text {sürtünme }}+\mathrm{F}_{\text {basnnç }}$

$\mathrm{C}_{\mathrm{D}}=\mathrm{C}_{\mathrm{D} \text {,sürtünme }}+\mathrm{C}_{\mathrm{D} \text {,basnnç }}$

$\mathrm{Bu}$, su araçlarının kuvvet testinde kullanılan temel yaklaşımdır. Basınca bağlı sürüklenme katsayısı ( $\left.\mathrm{C}_{\mathrm{D} \text {,basıņ̧ }}\right)$, akış frekansının

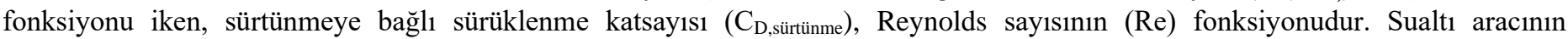
geometrisi, akış çizgileri ile paralel duruma getirilerek akış ayrılması ortadan kaldırılmaya çalışılmakta ve toplam sürüklenme kuvveti $F_{D}$, azaltılmaya çalışılır. Farklı geometrilere sahip katı gövde yapılarının dış akış analizlerinden elde edilen sonuçlardan, $R_{e}>10^{4}$ için $\mathrm{C}_{\mathrm{D}}$ değerinin sabit olduğu gözlenmiştir (Öztop, 2014). 
Basınç ve akışkanın yüzeyde oluşturduğu sürtünme kuvvetlerinin akışa dik doğrultudaki bileşenleri, araç gövdesini aynı yönde hareket etmeye zorlar. Bu zorlanma etkisine kaldırma denir. Kaldırma katsayısı $\mathrm{C}_{\mathrm{L}}$, aracın, yatay eksen etrafındaki dönme hareketinden (roll) oldukça etkilenir. Dönme hareketinin $C_{D}$ üzerindeki etkisi ise çok küçüktür.

\section{Simülasyon Modellerinin Tasarımı}

$\mathrm{Bu}$ çalışmada, hidrodinamik özellikleri incelenecek sualtı aracının (şekil 2), bilgisayar destekli çizim programı SolidWorks ile bire bir ölçülerde tasarlanan 3B modeli (şekil 3) kullanılmıştır. ISA modelinin, Solid Works ticari programı ile belirlenmiş olan bazı parametreleri Tablo 1'de görülmektedir.

Tablo 1. İSA’ya ait bazı fiziksel özellikler

\begin{tabular}{cc}
\hline Özellik & Değer \\
\hline Kuru kütle $(\mathrm{kg})$ & 33.87 \\
Boy $(\mathrm{m})$ & 0.62 \\
En $(\mathrm{m})$ & 0.42 \\
Yükseklik $(\mathrm{m})$ & 0.36 \\
Hacim $\left(\mathrm{m}^{3}\right)$ & 0.01 \\
Yüzey alanı $\left(\mathrm{m}^{2}\right)$ & 1.52 \\
\hline
\end{tabular}

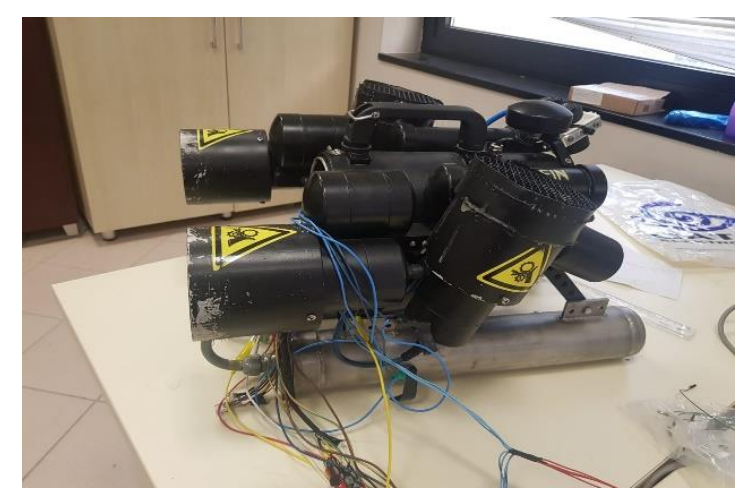

Şekil 2. İnsansız Sualtı Aracı (İSA)

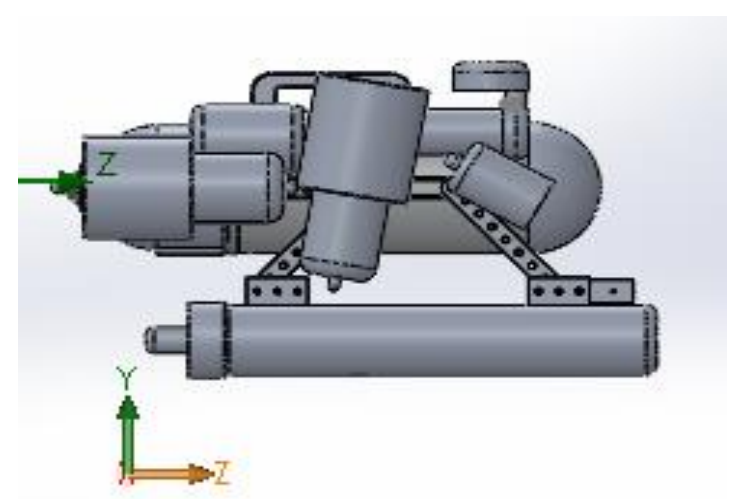

Şekil 3. İSA’nın 3B CAD Modeli

Şekil 2'de görülen İSA; elektronik kontrol kartları ve bağlantı kablolarını muhafaza eden silindirik bir ana gövde, ikisi yat ay diğer ikisi dikey itme sağlayan 4 motor, dengeleme amaçlı dubalar, kamera, lamba ve ayak kısmında besleme sağlayan Lityum bataryaları muhafaza eden iki kurşun silindirden oluşmaktadır. Gövde yapısı genel olarak sert PVC'den üretilmiş ve sıvı sızdırmazlığı sağlanmıştır. İSA'nın 3B CAD modeline, SolidWorks'ta kullanılmış olan metaryallerin ataması yapıldıktan sonra kütlesi $33.87 \mathrm{~kg}$ olarak belirlenmiştir. Bu değer aracın tartılan kütlesi ile uyumludur. Araç geometrik yapısı açısından literatürde yaygın olarak karşılaşılan silindirik veya torpido tipindeki araçlara göre farklılık gösterir. Bu farklılık, hidrodinamik parametrelerinin analitik yöntemler ile belirlenmesini çok güçleştirmektedir. Bu çalışma, karmaşık geometriye sahip İSA'lar için kontrolör tasarımında gerekli olacak dinamik modellerinin elde edilmesi açısından çalışma alanına katkı sunacaktır.

Reynolds-Ortalamalı Navier-Stokes (RANS) denklemleri türbülanslı akış analizlerinde, türbülans modelleri yardımıyla çözülen Navier-Stokes denklemleridir. Bu denklemlerde, akış özellikleri zaman-ortalamalı ve zamana bağlı değişen kısım olmak üzere iki bileşene ayrılmıştır. Örneğin hız büyüklüğünün bileşenlere ayrılması eşitlik (7)'deki gibidir:

$u_{i}=\bar{u}_{i}+u_{i}^{\prime}$

Burada $\bar{u}_{i}$ hızın zamana göre ortalamasını, $u_{i}^{\prime}$ ise zamana bağlı hız miktarının ortalama değer ile olan farkını temsil etmektedir. Zamana bağlı çözülen RANS denklemleri Zamana-bağlı Reynolds-Ortalamalı Navier-Stokes (URANS) denklemleri olarak adlandırılır. Süreklilik denklemi ve URANS denklemleri sırasıyla eşitlik (8) ve (9)'da verilmektedir.

$\frac{\partial \rho}{\partial t}+\frac{\partial}{\partial x_{i}}\left(\rho u_{i}\right)=0$

$\frac{\partial}{\partial t}\left(\rho u_{i}\right)+\frac{\partial}{\partial x_{j}}\left(\rho u_{i} u_{j}\right)=-\frac{\partial p}{\partial x_{i}}+\frac{\partial}{\partial x_{j}}\left[\mu\left(\frac{\partial u_{i}}{\partial x_{j}}+\frac{\partial u_{j}}{\partial x_{i}}-\frac{2}{3} \delta_{i j} \frac{\partial u_{1}}{\partial x_{1}}\right)\right]+\frac{\partial}{\partial x_{j}}\left(-\rho \overline{u_{\imath}^{\prime} u_{J}^{\prime}}\right)$ 
Eşitlik (9)'daki $\left(-\rho \overline{u^{\prime}}{ }_{\imath} u_{j}^{\prime}\right)$ terimi Reynolds gerilmesi olarak isimlendirilir. Burada $u_{i}^{\prime}$ ve $u_{j}^{\prime}$, sırasıyla x-yönündeki ve y-yönündeki hızın bu yönlerdeki ortalama hız değerlerinden anlık sapma miktarlarıdır. Türbülans olayının kaotik yapısından ötürü bu değerlerin hesaplandığı analitik bir yöntem mevcut değildir. Bu nedenle Reynolds gerilmesi hesaplanırken ortalama hızdan sapma değerleri bazı yaklaşımlar kullanılarak hesaplanır. Türbülans modelleri bu değerlerin hesaplanabilmesi için geliştirilmiştir (Apaçoğlu, 2010).

Sualtı aracının, akışın düzenli olmadı̆̆ 1 açık deniz sularında çalışacağı varsayılarak akış analizindeki akışkan örneği sıkıştırılamaz, açık kanal ve türbülanslı olarak belirlenmiştir. Türbülanslı akışa yönelik çözüm, türbülanslı kinetik enerji ve dağılım oranıyla ilgili iki denklemden oluşan $k-\varepsilon$ akış modelidir. İki denklemli türbülans modelleri arasında ekonomikliği ve pek çok akış olayında kabul edilebilir doğrulukta sonuç vermesi açısından yaygın olarak kullanılan yarı ampirik bir modeldir. Türbülans kinetik enerjisi $(\mathrm{k})$ ve dissipasyon oranı $(\varepsilon)$ için yazılan iki adet transport denkleminin çözümünü ve türbülans viskozitesinin hesabını içerir (Kaya ve Karagöz, 2007). Bu transport denklemleri k ve $\varepsilon$ için sırası ile;

$\rho \frac{D k}{D t}=\frac{d}{d x_{i}}\left(\Gamma_{k} \frac{d k}{d x_{i}}\right)+G_{k}-\rho \varepsilon$

$\rho \frac{D \varepsilon}{D t}=\frac{d}{d x_{i}}\left(\Gamma_{\varepsilon} \frac{d \varepsilon}{d x_{i}}\right)+C_{1 \varepsilon} \frac{\varepsilon}{k} G_{k}-C_{2 \varepsilon} \rho \frac{\varepsilon^{2}}{k}-\mathrm{R}$

şeklinde yazılabilir. Bu modelde difüzivite terimleri;

$\Gamma_{k}=\mu+\mu_{t} / \sigma_{k}, \quad \Gamma_{\varepsilon}=\mu+\mu_{t} / \sigma_{\varepsilon}$

hız gradiyentinden kaynaklanan türbülans kinetik enerjisi üretimini ifade eden terim;

$G_{k}=\mu_{t}\left(\frac{d u_{i}}{d x_{j}}+\frac{d u_{j}}{d x_{i}}\right) \frac{d u_{i}}{d x_{j}}$

olup burada türbülans viskozitesi, türbülans kinetik enerjisi ve dissipasyon oranı cinsinden eşitlik 14’teki gibi yazılır.

$\mu_{t}=\rho C \mu^{\frac{k^{2}}{\varepsilon}}$

$\mathrm{Bu}$ çalışmada, İSA modelinin hareketsiz (statik) olduğu, etrafındaki akışkanın araç hızında hareket ettiğinin varsayıldığı bir mesh yöntemi kullanılmıştır. $0.1 \mathrm{~m} / \mathrm{s}$ akış hızı için $0.5 \mathrm{~m}$ ve $1 \mathrm{~m}$ derinlikler için ve $0.5 \mathrm{~m} / \mathrm{s}$ ve $1 \mathrm{~m} / \mathrm{s}$ akış hızları için; $0.5 \mathrm{~m}, 1 \mathrm{~m}, 1.5 \mathrm{~m}$ ve 2 $m$ derinliklerde dış akış simülasyonları gerçekleştirilmiştir. İSA'nın batma derinliği arttıkça, yüzey dalgalarının $C_{D}$ ve $C_{L} k_{\text {katsayıları }}$ üzerindeki etkileri incelenmiştir. Bu çalışmada, akış analizleri için bilgisayar destekli tasarım programı SolidWorks'un eklentisi olarak çalışan Flow Simulation programı kullanılmıştır.

\section{1 k- $\varepsilon$ modeli için ağdan bağımsızlık analizi}

Hidrodinamik analizlerde, akış alanı ağ yapısı çok önemlidir. Bunun sebebi, ağ yapısı ve miktarının, hidrodinamik analizin doğruluğu ve işlem yükü üzerinde belirleyici olmasıdır. Bu nedenle analize başlamadan önce, en uygun ağ miktarını belirleme simülasyonları gerçekleştirildi. Aracın 3B modelinde bazı parçalar devre dışı bırakılarak modelde sadeleşmeler yapıldı. Böylelikle işlem yükü hafifletildi. Şekil 4'te görüldüğü üzere araç gövdesinin akışkan ile temas ettiği yüzeyler, daha küçük ağ yapısı ile kaplanarak araç geometrisi yakalanmaya çalışıldı.

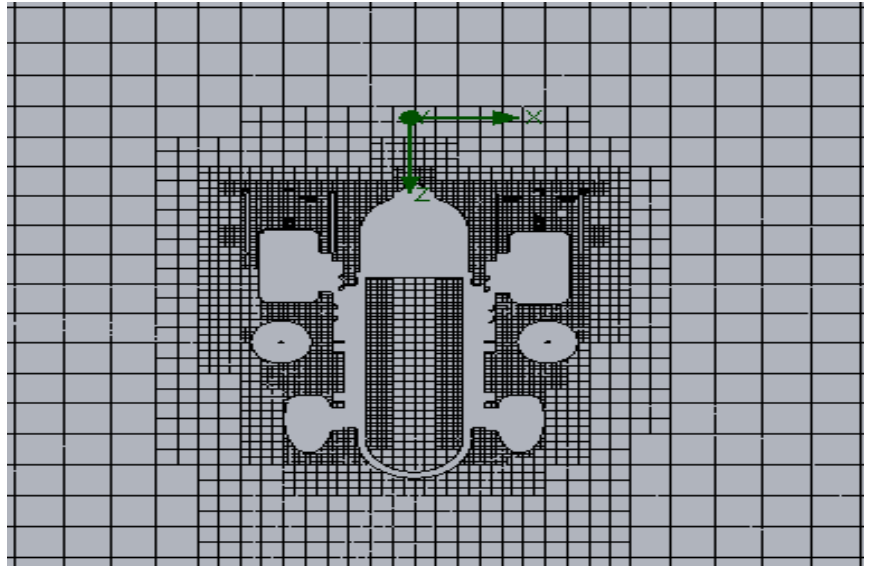

Şekil 4. Araç gövdesi ve akışkan arayüzü ağ yapısı

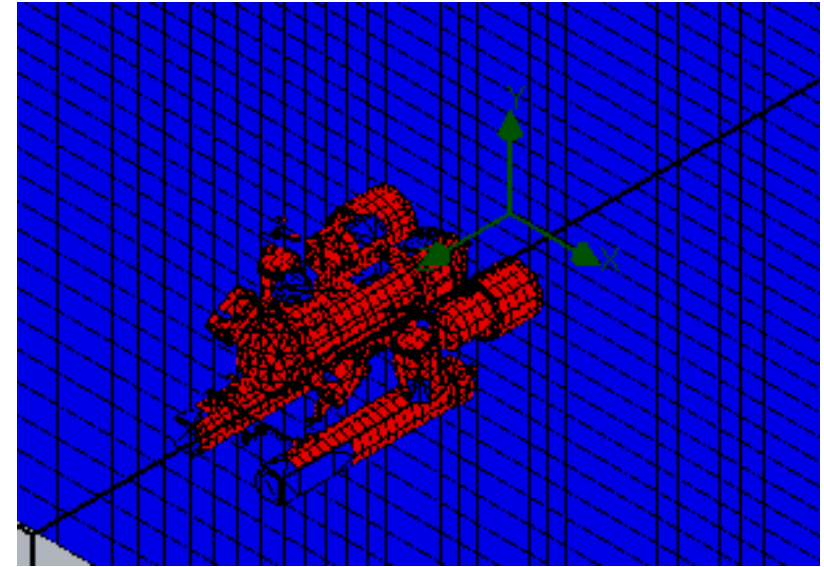

Şekil 5. Araç gövdesi üzerindeki 3 boyutlu hacimsel ağ yapısı 
Araç modeli ile, yaklaşık 4 x $10^{3}$ değerindeki Reynolds sayısı için 4 farklı ağ sayısında ağdan bağımsızlık testleri yapılmıştır (Tablo.2). Analiz 846930 ağ sayısında iken, $C_{D}$ değerlerinin ağ sayısından önemli ölçüde etkilenmediği gözlenmiştir.

Tablo 2. Ağ bağımsızlığı testi sonuçları

\begin{tabular}{ccc}
\hline A ̆ Sayıs1 & $\begin{array}{c}\text { Sürüklenme Kuvveti } \\
\left(F_{D}\right)\end{array}$ & $\begin{array}{c}\text { Sürüklenme Katsayıs1 } \\
\left(C_{D}\right)\end{array}$ \\
\hline 45586 & $0.2852 \mathrm{~N}$ & 0.3209 \\
108040 & $0.3055 \mathrm{~N}$ & 0.3439 \\
235210 & $0.2904 \mathrm{~N}$ & 0.3258 \\
846930 & $0.2905 \mathrm{~N}$ & 0.3269 \\
\hline
\end{tabular}

\subsection{Kurulum ve Sayısal Çözüm}

Araç modelini çevreleyen sıvı akışını modellemek ve çözmek için ticari Solid Works programı ile birlikte çalışan FlowSimulation HAD programı kullanılmıştır. Hesaplamalar için, araç gövdesini çevreleyen akış alanı ve su basıncı, akışkanın sıkıştıılamaz, izotermal RANS (Reynold Ortalamalı Navier Stokes) denklemleri ile hareket modellemesine dayalı olarak belirlenmiştir. Analizlerde 3 boyutlu hacimsel dış akış modeli kullanılmıştır. Akışkan-katı etkileşim bölgesi hücre sayısı : 19190, akışkan olarak ise deniz seviyesi atmosfer basıncı aktında ve $293.2{ }^{0} \mathrm{~K}$ sıcaklıktaki su seçilmiştir. Bu koşullardaki suyun yoğunluğu $\rho=998.2 \mathrm{~kg} / \mathrm{m}^{3}$, viskozitesi ise $\mu=$ 0.0010115 (Pa.s)'dir. Türbülanslı akış modeli olarak k- $\varepsilon$ modeli kullanılmıştır. Türbülans parametreleri; intensity $=\% 0.1$, length $=$ $0.003 \mathrm{~m}$ seçilmiştir. Hesaplama bölgesi $6 \mathrm{~m}$ (uzunluk) x $4 \mathrm{~m}$ (genişlik) x $3 \mathrm{~m}$ (derinlik) olacak şekilde dikdörtgen prizma şeklinde belirlenmiştir. Aracın boyutları ise yaklaşık olarak $0.36 \mathrm{~m}$ x $0.42 \mathrm{~m} \mathrm{x} 0.62$ m'dir. Şekil 4'te görüldüğü üzere, sıvı ve katı model etkileşiminin olduğu yüzeylerde daha ince bir ağ yapısı kullanılmıştır. Bu hacim, gerekli hesapsal doğruluk için yeterlidir. Sınır koşulu olarak ideal duvar seçilmiştir. Global Goals : Force Z ve Force Y olarak seçilmiş, Equation Goals $1: C_{D}=\{G G$ Force $(Z)$ $y /\left(0.5 * 998.2 * 0.5^{\wedge} 2 * 0.178\right)$ Equation Goals2 : $C_{L}=\{$ GG Force $(Y)\} /\left(0.5 * 998.2 * 0.5^{\wedge} 2 * 0.382\right)$ şeklinde formül olarak girilmiştir.

Sıvı içerisine tamamen batmış şekilde hareket eden bir sualtı aracı gövdesine etki eden kaldırma ve sürüklenme kuvvetleri ile bunlara bağlı olarak değişen kaldırma ve sürükleme katsayılarının, hareket derinliğine bağlı değişimlerini HAD çözüm yöntemleri aracıllğı ile gözlemlemek, bu çalışmanın amaçlarından biridir. Bunun için, araç gövdesi sıvı yüzeyinden itibaren sırasıyla $0.5 \mathrm{~m}, 1 \mathrm{~m}, 1.5 \mathrm{~m}$, ve 2 $\mathrm{m}$ derinliklere dalmış durumda iken ve yatay düzlemde $0.5 \mathrm{~m} / \mathrm{s}$ ile $1 \mathrm{~m} / \mathrm{s}$ hızlarla hareket ederken, araç gövdesine etki eden sürükleme kuvveti $F_{D}$ ve kaldırma kuvveti $F_{L}$ hesaplanmıştır. Equation Goals simülasyon parametresi, $C_{D}$ ve $C_{L}$ değerlerini hesaplamak amacıyla eşitlik (3) ve (4)'e göre tanımlanmış denklemlerdir. Aracın, yatay ve dikey düzlem alanları sırasıyla $0.178 \mathrm{~m}^{2}$ ve $0.382 \mathrm{~m}^{2}$ olarak SolidWorks tarafından hesaplanmıştır.

\section{Analiz Sonuçları}

Araç modeli etrafındaki akışın, k-E türbülans modeli çözümünden elde edilen, toplam sürüklenme kuvveti ve sürüklenme katsayısı, farklı derinlikler ve iki farklı hız değeri için Tablo 3' te listelenmiş ve Şekil 6'da grafiksel olarak sunulmuştur.

Tablo 3. Hidrodinamik özelliklerin derinliğe bağlı değişimi (akış hızı v=0.5 m/s için).

\begin{tabular}{ccccc}
\hline Derinlik $(\mathbf{m})$ & $\begin{array}{c}\text { Sürüklenme } \\
\text { Kuvveti } \\
(\mathbf{N})\end{array}$ & $\begin{array}{c}\text { Kaldırma } \\
\text { Kuvveti } \\
(\mathbf{N})\end{array}$ & $\begin{array}{c}\text { Sürüklenme } \\
\text { Katsayısı } \\
\left(\mathbf{C D}_{\mathbf{D}}\right)\end{array}$ & $\begin{array}{c}\text { Kaldırma } \\
\text { Katsayısı } \\
\left(\mathbf{C}_{\mathbf{L}}\right)\end{array}$ \\
\hline 0.5 & 5.228 & -0.471 & 0.243 & -0.0098 \\
1 & 5.525 & -0.509 & 0.257 & -0.0106 \\
1.5 & 5.828 & -0.0704 & 0.271 & -0.00147 \\
2 & 5.869 & 0.098 & 0.273 & 0.0021 \\
\hline
\end{tabular}



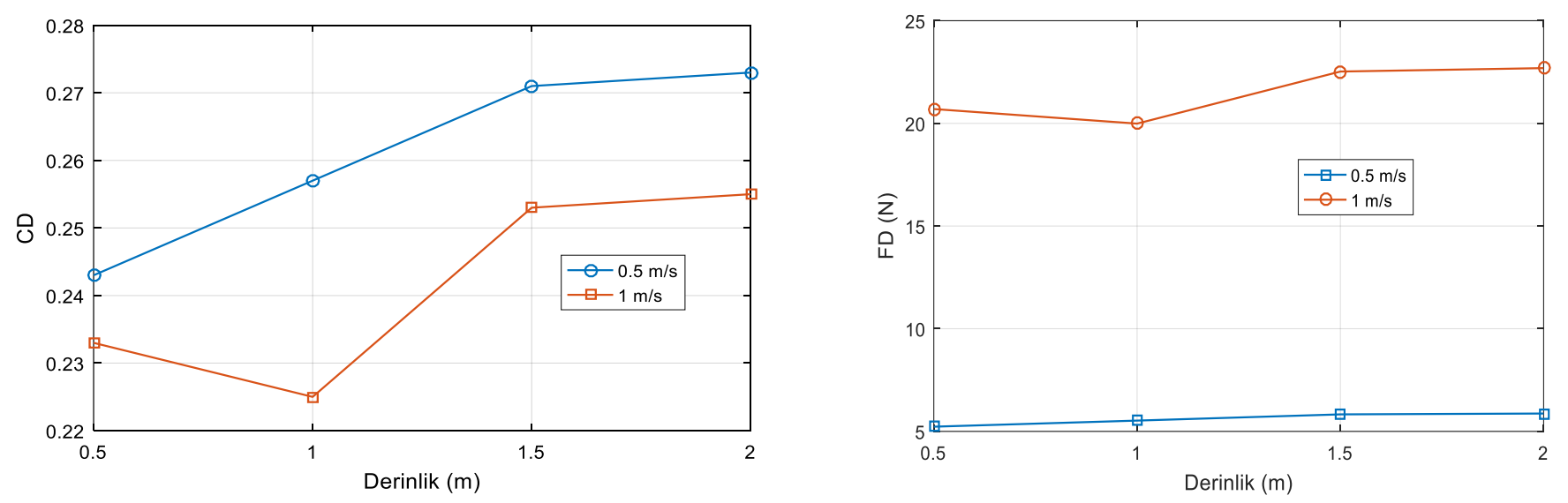

Şekil 6. Derinlik ve hızın fonksiyonu olarak sürükleme katsayısı sürükleme kuvveti

İncelenen iki akış hızı için $(0.5 \mathrm{~m} / \mathrm{s}$ ve $1 \mathrm{~m} / \mathrm{s})$, dalma derinliği $1 \mathrm{~m}$ 'yi geçtiğinde, araç gövdesi ile temas eden akışkan miktarındaki artış viskoziteyi arturdığından $F_{D}$ ve $C_{D}$ artış göstermektedir. Bu derinlikten itibaren her iki hız değeri için 1.5 m'den ve 2 m'ye kadar olan derinlik değişiminde hem $C_{D}$ hem de $F_{D}$ değeri neredeyse sabit kalmaktadır. En düşük $C D$ ve $F D$ değerleri araç yüzeye yakın hareket ederken kaydedilmiştir. Hareket hızları çok yüksek olmadığından yüzey etkileri fazla gözlenmemiştir. Herhangi bir derinlik için, araç etrafındaki akış hızı arttıkça, sürüklenme kuvveti $\mathrm{F}_{\mathrm{D}}$ artarken, sürüklenme katsayısı $C_{D}$ 'nin azaldığı gözlendi.

Araç modeli etrafındaki akıştan kaynaklanan toplam kaldırma kuvveti ve kaldırma kuvveti katsayısı, farklı derinlikler ve iki farklı hız değeri için Tablo 4' de listelenmiş ve Şekil 7'de grafiksel olarak sunulmuştur.

Tablo 4. Hidrodinamik özelliklerin derinliğe bağlı değişimi (akış hızı v=1 m/s için).

\begin{tabular}{ccccc}
\hline Derinlik $(\mathbf{m})$ & $\begin{array}{c}\text { Sürüklenme } \\
\text { Kuvveti } \\
(\mathbf{N})\end{array}$ & $\begin{array}{c}\text { Kaldırma } \\
\text { Kuvveti } \\
(\mathbf{N})\end{array}$ & $\begin{array}{c}\text { Sürüklenme } \\
\text { Katsayısi } \\
\left(\mathbf{C}_{\mathbf{D}}\right)\end{array}$ & $\begin{array}{c}\text { Kaldırma } \\
\text { KatsayıSI } \\
\left(\mathbf{C}_{\mathbf{L}}\right)\end{array}$ \\
\hline 0.5 & 20.698 & -1.944 & 0.233 & -0.0102 \\
1 & 19.988 & -2.306 & 0.225 & -0.0121 \\
1.5 & 22.524 & 0.304 & 0.253 & 0.0016 \\
2 & 22.691 & 0.609 & 0.255 & 0.0032 \\
\hline
\end{tabular}
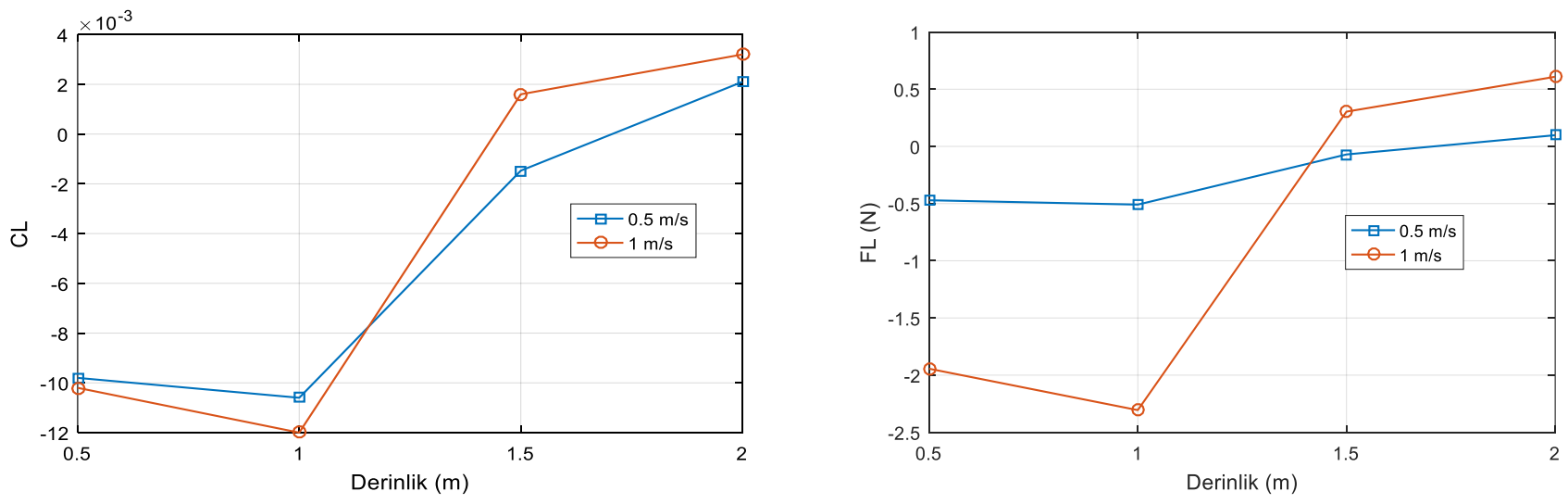

Şekil 7. Derinlik ve hızın fonksiyonu olarak kaldırma katsayısı ve kaldırma kuvveti

Sonuçlar dikkatli bir şekilde gözlemlendiğinde, yüzeye yakın kaldırma kuvvetinin yönünün ve büyüklüğünün, İSA'nın yüzeye yakın hareket etme hızına bağlı olduğu görülmektedir. Ayrıca, derinlik arttıkça, kaldırma katsayısının da arttığı, $1.5-2 \mathrm{~m}$ aralığında bu artışın azaldığı gözlenmiştir. Kaldırma kuvveti ise belli derinlikten sonra (yaklaşık $1.4 \mathrm{~m}$ ) hıza bağlı olarak artmıştır. Derinlik 1 m’yi geçtikten sonra kaldırma katsayısında keskin bir değişme olduğu görülmektedir. Bu keskin değiş̧imin, araç geometrisinin x-z düzleminde yeterince simetrik olmaması sonucu, dalış sırasında yatay eksen etrafinda bir miktar dönme yapmasından 
kaynaklandığı düşünülebilir. Deneysel çalışmalarla da gözlenmiștir ki, akıș hızının yüksek olduğu durumlarda, kaldırma katsayısı derinlikle artmaktadır (Mansoorzadeh vd., 2014). Su yüzeyine yakınken kaldırma kuvvetinin yönü ve büyüklügü̈, hıza bağlı olarak değişmektedir. Bu aynı zamanda İSA’nın gövde yapısının geometrisine ve simetriklik durumuna da bağlıdır.

Şekil 8'de, araç gövdesinin, $2 \mathrm{~m}$ ve $0.5 \mathrm{~m}$ derinliklerdeki hareketi sırasında analizler sonucu elde edilen hız dağılım profilleri görünmektedir. Akış hızı dağılımından da görüldüğü üzere, araç su yüzeyinden derine indikçe yüzey dalgalanmalarının etkisi azalmakta, basınçtan kaynaklı sürüklenme kuvveti artmaktadır. Gövde yüzeyindeki sürtünmeler artmakta ve hız değerleri düşmektedir. $\mathrm{Bu}$ da derin sularda hareket ederken $\mathrm{C}_{\mathrm{d}}$ değerinin daha büyük olmasını açıklamaktadır. Araç gövdesinin ön kısmındaki hız değeri, 0.5 $\mathrm{m}$ derinlikte $0.348 \mathrm{~m} / \mathrm{s}$ civarında iken, $2 \mathrm{~m}$ derinlikte bu değer $0.312 \mathrm{~m} / \mathrm{s}$ civarındadır.

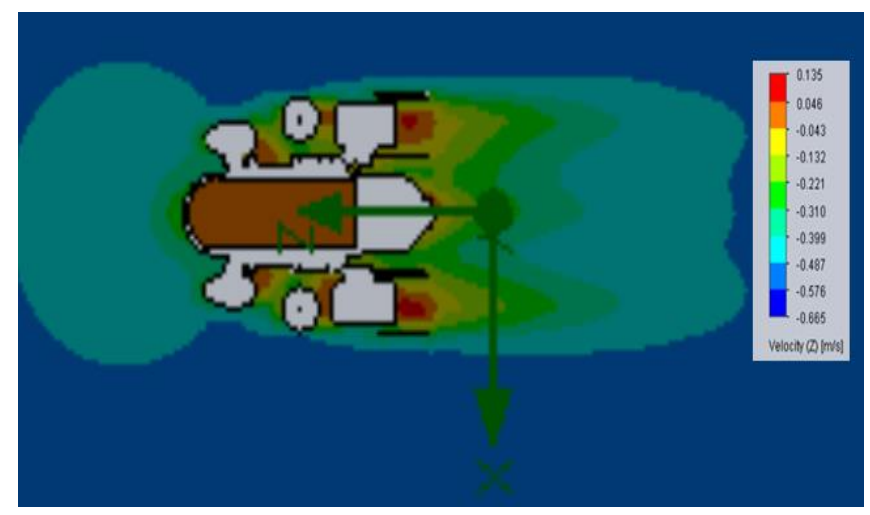

(a)

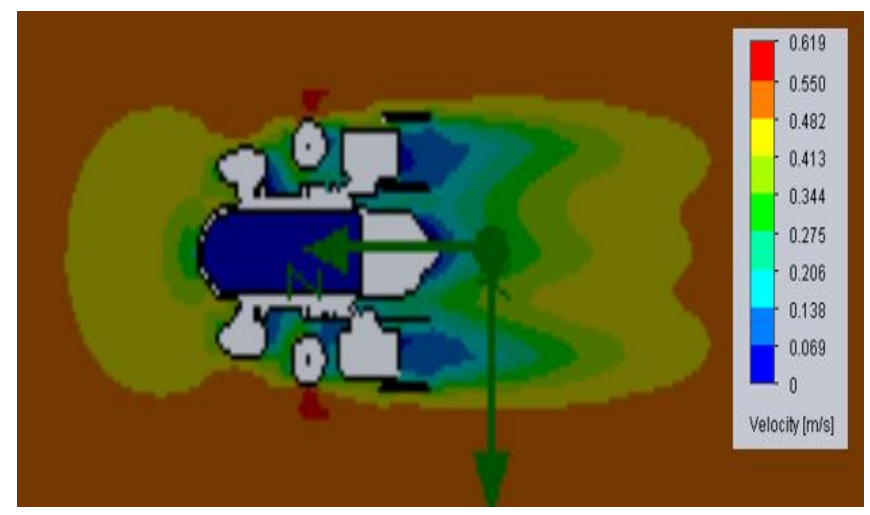

(b)

Şekil 8. İSA etrafındaki akışkan hız dağılımı ( $0.5 \mathrm{~m} / \mathrm{s}$ hız ve (a) $2 \mathrm{~m}$ (b). $0.5 \mathrm{~m}$ derinlik için)

İSA'nın, dikey düzlemde $0.1 \mathrm{~m} / \mathrm{s}$ akış hızı için dış akış simülasyonu sonucu elde edilen hız dağılımı şekil 9'da görülmektedir. Şekilden de görüleceği üzere, akışkan sürtünmelerinin sebep olduğu dönme momenti, dönmeye sebep olmuş bu da aracın arka kısmında akış ayrılması oluşturmuş̧ur. Ayrıca hızın düşük olması da akış ayrılmasına neden olmuş olabilir. araç yüzeyi üzerindeki sürtünme kuvveti, diğer analizlere göre düşük hız nedeniyle daha yüksektir. Bu nedenle gövde etrafinda hız düşüşleri görülmektedir.

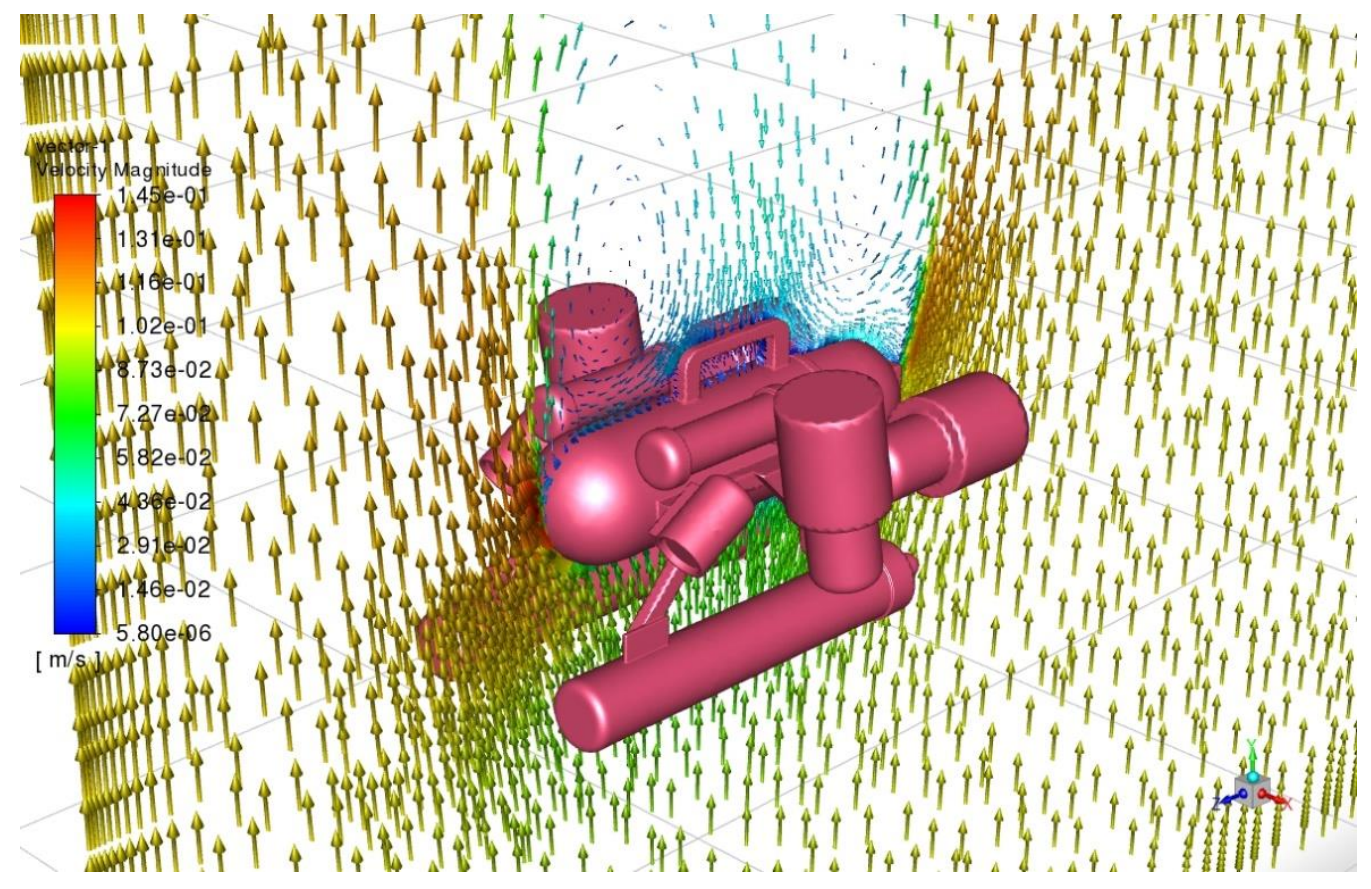

Şekil 9. Dikey hareket için İSA etrafındaki akışkan hız dağılımı $(0.1 \mathrm{~m} / \mathrm{s})$

\section{Deneysel Çalıșmalar}

4 serbestlik dereceli (yatay ve dikey eksenlerde doğrusal öteleme ve bu eksenler etrafinda açısal dönme) otonom sualtı aracının, Kocaeli Üniversitesi Elektronik ve Haberleşme Mühendisliği bölümünde bulunan sualtı aracı deney platformlarında bazı testleri 
gerçeklenmiştir. Yatay eksende doğrusal öteleme hareketi testi için kullanılan deney platformu, $2.5 \mathrm{~m}$ çapa ve $1.5 \mathrm{~m}$ derinliğe sahip dairesel bir havuzdur. Dikey eksende batma testi için kullanılan platform ise yüksekliği $2 \mathrm{~m}$, çapı $80 \mathrm{~cm}$ olan bir silindirdir (şekil $10 \mathrm{a}$ ve b).

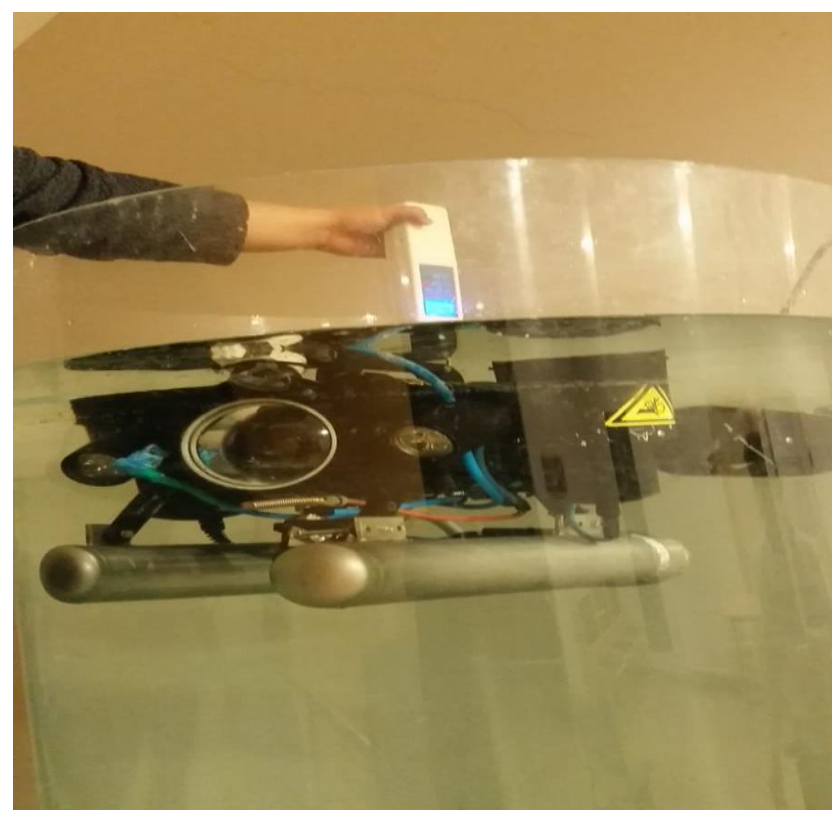

(a)

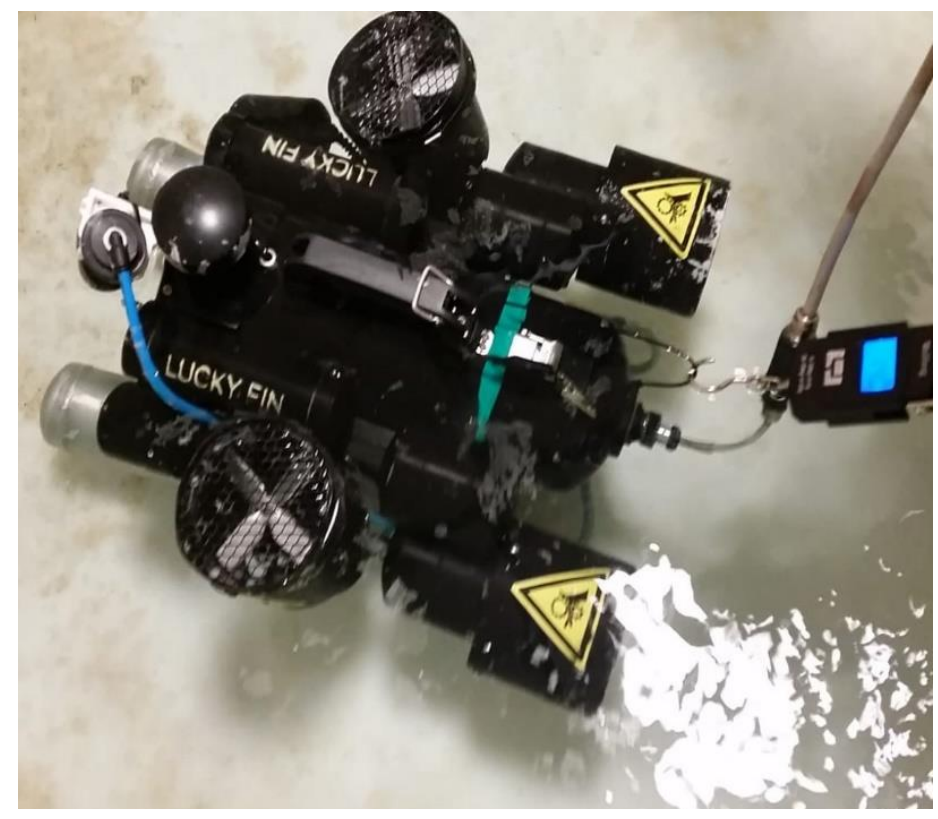

(b)

Şekil 10. Testler için kullanılan deney platformları a) silindirik platform b). dairesel platform

Test çalışmaları sırasında araç, $0.5 \mathrm{~m}$ ve $1 \mathrm{~m}$ derinliklere daldılarak yaklaşık $0.1 \mathrm{~m} / \mathrm{s} \mathrm{h}$ ız değerinde yatay eksende doğrusal öteleme hareketi yaptırılmıştır. Bu hareket sırasında yatay motorların itme kuvveti ile suyun sürtünme kuvveti arasındaki fark olan net kuvvetler, dijital dinamometre ile ölçülmüsstür. Bu net kuvvet, yatay motorların itme kuvvetinden çıkartılarak sürtünme kuvvetleri belirlenmiştir. Bu değerler, sayısal hesaplamalar sonucu elde edilen kuvvet değerleri ile karşılaştırıldığında, HAD analizlerinin sonuçlarını doğrular niteliktedir (Tablo 5).

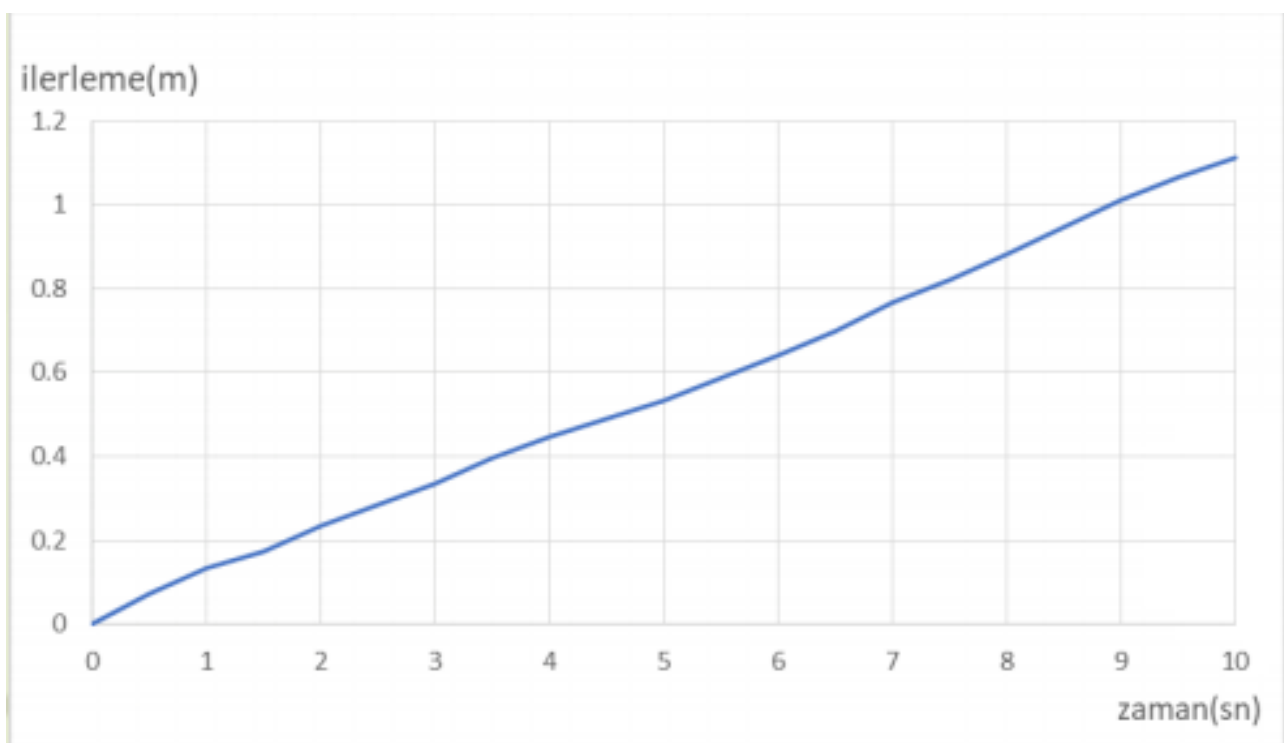

Şekil 11. İSA’nın tam PWM ileri geri öteleme hareketi deney verileri 


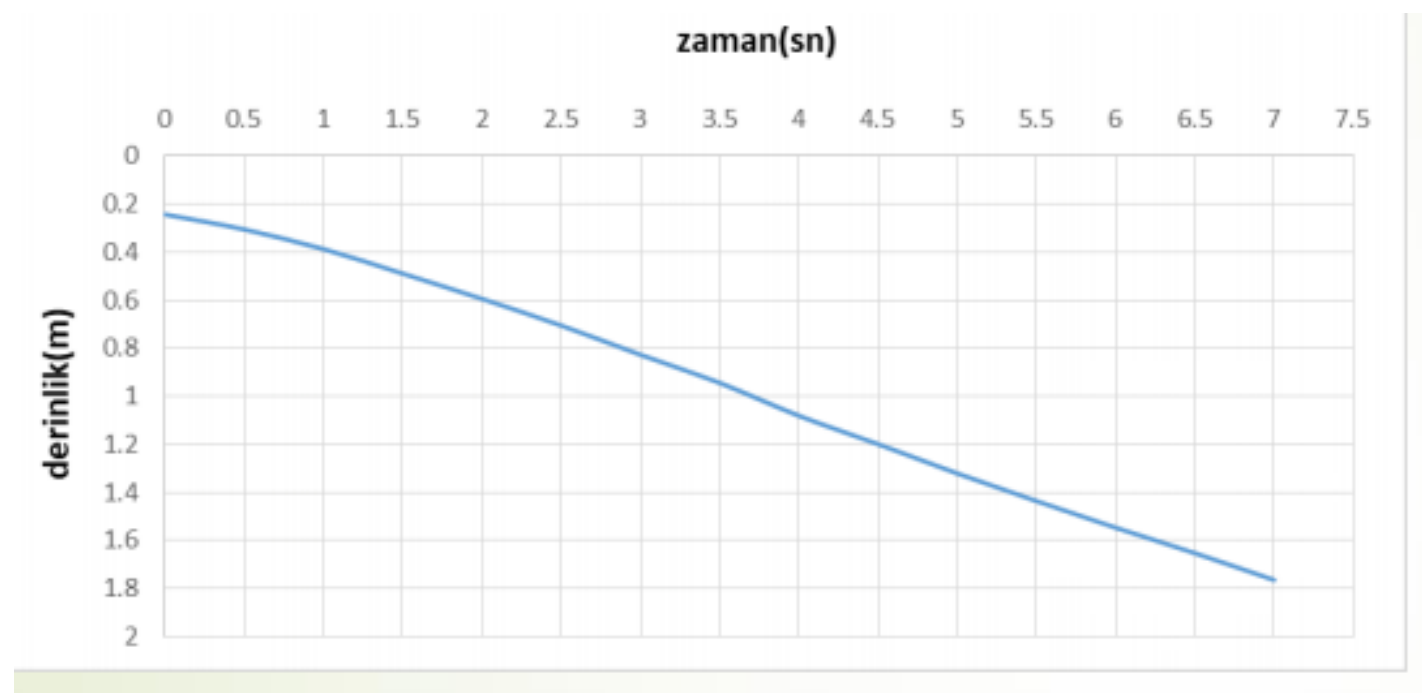

Şekil 12. İSA'nın tam PWM aşağı yukarı öteleme hareketi deney verileri

Hem yatay hem de dikey hareketler için yol-zaman grafiklerinden (şekil 11 ve 12), hız yaklaşı olarak $0.1 \mathrm{~m} / \mathrm{s}$ olarak elde edilmiştir. $C_{D}$ ve $C_{L}$, deneysel ölçümlerden elde edilen sürtünme kuvvetleri kullanılarak eşitlik (3) ve (4)'e göre hesaplama yoluyla elde edilmiştir. İSA'nın, tam PWM çalışmada ulaşabildiği hız değeri yaklaşık $0.1 \mathrm{~m} / \mathrm{s}$ olduğundan, karşıllaştırmaların yapılabilmesi için bu akış hızında HAD analizleri tekrar yapılmıştır ( $0.5 \mathrm{~m}$ ve $1 \mathrm{~m}$ dalma derinlikleri için). $0.1 \mathrm{~m} / \mathrm{s}$ akış hızı için Reynolds sayısı yaklaşık olarak 350 civarındadır. Bu da akışın laminar olduğu anlamına gelmektedir. Akış analizleri yapılırken sadece laminar akış seçilmiştir. Diğer akış hızları, $0.5 \mathrm{~m} / \mathrm{s}$ ve $1 \mathrm{~m} / \mathrm{s}$ için ise ( $\operatorname{Re} \approx 1700$ ve Re $\approx 3500$ ), laminar ve laminar + türbülanslı akış birlikte seçilmiştir. Diğger akış analizi parametreleri, önceki analizler ile aynıdır.

Sürüklenme kuvveti katsayısı $\left(C_{D}\right)$ ve kaldırma kuvveti katsayısı $\left(C_{L}\right)^{\prime}$ nin sayısal analizler ve deneysel ölçümlerden elde edilen değerleri arasındaki fark, analizlerde kullanılan hesaplama alanının, deney platformlarından şekil ve boyut olarak farklı olmasından kaynaklanmaktadır. Her ne kadar sayısal çözümlerde akış laminar olarak belirlenmiş olsa da deneysel ölçümler sırasında kısa mesafede duvara çarpıp dönen dalgaların hidrodinamik kuvvet ve momentler üzerinde bozucu etkileri olmuştur ve bu da sonuçlar üzerinde etkilidir. Bir diğer etken ise, motorlar çalışırken dönen pervanelerin, sayısal analizlerde göz ardı edilmiş olmasıdır.

Tablo 5. 0.5 ve $1 \mathrm{~m}$ derinlikler için deneylerden ve HAD analizlerinden elde edilen sürüklenme ve kaldırma kuvvetleri katsayılarının karşıllaştırılması $($ hız $=0.1 \mathrm{~m} / \mathrm{s})$

\begin{tabular}{ccccc}
\hline Metod & $\mathrm{C}_{\mathrm{D}}(0.5 \mathrm{~m})$ & $\mathrm{C}_{\mathrm{L}}(0.5 \mathrm{~m})$ & $\mathrm{C}_{\mathrm{D}}(1 \mathrm{~m})$ & $\mathrm{C}_{\mathrm{L}}(1 \mathrm{~m})$ \\
\hline HAD & 0.3374 & 0.4617 & 0.3258 & 0.4114 \\
Deneysel ölçümler & 0.3502 & 0.5128 & 0.3401 & 0.4491 \\
Error $(\%)$ & 3.79 & 11.06 & 4.38 & 9.16 \\
\hline
\end{tabular}

\section{Sonuçlar}

Bu çalışmada, bir İSA’nın sürüklenme ve kaldırma kuvvetleri ve bu kuvvetlere bağlı katsayıların derinliğe bağlı nasıl değiştiğini görmek amacıyla laminar ve laminar-türbülanslı geçiş akış analizleri yapılmıştır. Sayısal analizlerde, İSA'nın 1:1 ölçülerdeki modeli kullanılmıştır. Araç gövdesinin çalışma derinliği arttıkça yüzey etkileri azalmıştır. Simulasyonlar, su yüzeyinden itibaren $0.5,1,1.5$, ve $2 \mathrm{~m}$ olmak üzere dört farklı derinlik için, $0.5 \mathrm{~m} / \mathrm{s}$ ve $1 \mathrm{~m} / \mathrm{s}$ akış hızlarında gerçekleştirilmiştir. Ayrıca, $0.5 \mathrm{~m}$ ve $1 \mathrm{~m}$ derinlikler için $0.1 \mathrm{~m} / \mathrm{s}$ akış hızında HAD analizleri ve deney platformunda test ölçümleri yapılmıştır. Deneysel çalışmalardan elde edilen sürüklenme ve kaldırma katsayıları, sayısal çözümlerden elde edilen değerlerle karşılaştırıldı̆̆ında tatmin edici düzeyde yakın bulunmuştur. Sonuçlar, sürtünme katsayıları üzerindeki yüzey etkisinin hem İSA hızının hem de batma derinliğinin bir fonksiyonu olduğunu ortaya koymuştur. Basınç direnci ve dolayısıyla dalga oluşturma direncine bağlı toplam sürükleme katsayısının, daha yüksek derinliklerde elde edilenlere göre serbest yüzeyin yakınında daha küçük olduğu gösterilmiştir. Akış hızı düştükçe sürükleme katsayıları daha yüksek çıkmıştır. Örneğin, İSA $1 \mathrm{~m} / \mathrm{s}^{\prime}$ lik hızda, $2 \mathrm{~m}$ derinlikte hareket ederken kaydedilen sürükleme katsayısı $0.255 \mathrm{iken}, 0.5 \mathrm{~m} / \mathrm{s}$ akış hızı ile aynı derinlikte hareketi sırasında bu değer $0.273^{\wedge}$ tür. 
Analiz sonuçlarına gör (şekil 8 ve 9), toplam sürüklenme kuvveti yüzeye yakın hareket halinde, yüzey dalgalanmaları ve akışkan viskozitesi kaynaklı iken daha derindeki hareketlerde basınç kaynaklıdır. Dış akış esnasında enerji tüketimini azaltmak için iki tür akış kontrol yöntemi uygulanabilir. Bunlardan biri, aracın aerodinamik yapısında iyileştirme yapmak, diğeri ise cisim yapısında herhangi bir değişiklik olmaksızın sistemde enerji kullanılarak cisim etrafındaki akışın kontrol edildiği yöntemdir. Bu iki yöntemden hangisinin kullanılacağına yapılacak HAD analizleri ve fizibilite hesaplaıyla karar verilebilir.

Bir İSA'nın kararlı hareket edebilmesi için kaldırma ve sürüklenme kuvvetleri gibi hidrodinamik etkileri karşılayabilecek itme kuvvetini motorları aracılığı ile sağlaması gerekmektedir. Optimum güç tüketiminin olması için aracın hangi derinlik ve hızda çalıştııılacağı önemlidir ve bu çalışma bu soruya yanıt bulabilmek ve gelecek çalışmalara ışık tutabilmek amacıyla yapılmıştır. Sayısal sonuçların doğruluğunun, deneysel ölçümlerle kanıtlanması sonucu, karmaşık geometrik yapıya sahip İSA'nın hidrodinamik model parametrelerinin belirlenmesinde HAD analizlerinden yararlanılabileceği sonucuna varılmıştır. Bazı özel görevler için tasarlanan İSA'lar, geometrik olarak torpido veya silindirik şekle sahip olmayabilirler ve düşük hızlarda çalışan İSA'ların akım çizgili formda tasarlanmaları zorunlu değildir.

\section{Referanslar}

Apaçoğlu, B. (2010), Silindir Üzerindeki Laminer ve Türbülanslı Akışın Kontrollü ve Kontrolsüz HAD Analizleri, TOBB Ekonomi ve Teknoloji Üniversitesi, Makine Mühendisliği Anabilim Dalı, Yüksek Lisans Tezi, http://earsiv.etu.edu.tr/xmlui/bitstream/handle/20.500.11851/298/TZ00102.pdf?sequence=1\&isAllowed=y

Du X., Wang H., Hao C., Li X., Analysis of hydrodynamic characteristics of unmanned underwater vehicle moving close to the sea bottom, Defence Technology, c. 10, sy 1, ss. 76-81, Mar. 2014, doi: 10.1016/j.dt.2014.01.007.

Javanmard E. A Computational Fluid Dynamics Investigation on the Drag Coefficient Measurement of an AUV in a Towing Tank, JAFM, c. 12, sy 3, ss. 947-959, May. 2019, doi: 10.29252/jafm.12.03.29525.

Karasu İ., Silindir Etrafındaki Kararsız Akışın Farklı Türbülans Modelleri ile Sayısal Olarak İncelenmesi, Bilecik Şeyh Edebali Üniversitesi Fen Bilimleri Dergisi, c. 6, sy 1, Haz. 2019, doi: 10.35193/bseufbd.560925

Kaya F., Karagöz İ., Investigation into the Suitability of Turbulence Models in Swirling Flows, Uludağ Üniversitesi MühendislikMimarlık Fakültesi Dergisi, Cilt 12, Sayı 1 s. 12, 2007.

Malavasi S. Guadagnini A. Interactions between a rectangular cylinder and a free-surface flow, Journal of Fluids and Structures, 23(8), 1137-1148, 2007.

Mansoorzadeh Sh., Javanmard E., An investigation of free surface effects on drag and lift coefficients of an autonomous underwater vehicle (AUV) using computational and experimental fluid dynamics methods, Journal of Fluids and Structures, c. 51, ss. 161-171, Kas. 2014, doi: 10.1016/j.jfluidstructs.2014.09.001.

Mitra A., Panda J. P., Warrior H. V., Experimental and numerical investigation of the hydrodynamic characteristics of Autonomous Underwater Vehicles over sea-beds with complex topography, arXiv:1904.13305 [physics], Nis. 2019, Erişim: Şub. 14, 2021.

[Çevrimiçi]. Erişim adresi: http://arxiv.org/abs/1904.13305.

Novais M., The Effect of Depth on Drag During the Streamlined Glide: A Three-Dimensional CFD Analysis, Journal of Human Kinetics, c. 33, sy 1, ss. 55-62, Haz. 2012, doi: 10.2478/v10078-012-0044-2.

Öztop H. F., Dış Akışlar Kaldırma ve Direnç, Fırat Üniversitesi Teknoloji Fakültesi Makine Mühendisliği Bölümü, Ders notu, 2014,

Erişim: http://hakanfoztop.com/wp-content/uploads/2019/02/11-D\%C4\%B1\%C5\%9F-ak\%C4\%B1\%C5\%9Flar-diren\%C3\%A7-vekald\%C4\%B1rma.pdf

Salari M. Rava A. Numerical investigation of hydrodynamic flow over an AUV moving in the water-surface vicinity considering the laminar-turbulent transition, J. Marine. Sci. Appl., c. 16, sy 3, ss. 298-304, Eyl. 2017, doi: 10.1007/s11804-017-1422-x

Shao WY. Zhang YP. Zhu DZ. Zhang TQ. Drag force on a free surface-piercing yawed circular cylinder in steady flow, Journal of Fluids and Structures, 43, 145-163, 2013.

Vorus WS, Paulling JR., The Principles of Naval Architecture, 2010 Series.

Yakut M., Yılmaz S., İnce S., Otcu M., Aygün E., Derinlik ve Yön Kontrol Uygulamaları için Sualtı Aracı Tasarımı, Gazi Üniversitesi Fen Bilimleri Dergisi Part:C, Tasarım Ve Teknoloji GU J Sci Part:C 3(1):343-355, 2015 
Yang R., Clement B., Mansour A., Li M., Wu N., Modeling of a Complex-Shaped Underwater Vehicle for Robust Control Scheme, J Intell Robot Syst, c. 80, sy 3-4, ss. 491-506, Ara. 2015, doi: 10.1007/s10846-015-0186-2.

Zhang H., Xu Y., Cai H., Using CFD software to calculate hydrodynamic coefficients, J. Marine. Sci. Appl., c. 9, sy 2, ss. 149-155, Haz. 2010, doi: 10.1007/s11804-010-9009-9.

Zhao M., Cheng L. Zhou T. Direct numerical simulation of three-dimensional flow past a yawed circular cylinder of infinite length. Journal of Fluids and Structures, 25(5), 831-847, 2009. 